\title{
A SCRIPT FOR HERSELF: CHARACTERIZATION AND FREE INDIRECT STYLE IN CONRAD'S VICTORY
}

\author{
UDC 821.111.09-31 Conrad J.
}

\author{
Nataša Tučev \\ University of Niš, Faculty of Philosophy, Niš, Serbia
}

\begin{abstract}
Some of the most influential studies written about Joseph Conrad in the 1950s (by Douglas Hewit, Thomas Moser and Albert Guerard) established a critical paradigm that continued to dominate Conrad studies for decades to come - especially with regard to his later novels, which according to these critics represented a decline after the achievements of his major period. The principal reason for this decline, as Moser argues, was Conrad's altered choice of subject matter from the novel Chance onwards - i.e., his newly-discovered interest in romance and female protagonists. Conrad's failure in representing intimate erotic relationship in his later novels, as Moser maintains, is inseparable from his inclination to create melodramatic and inauthentic heroines, incomparably less complex than the striking male protagonists of his earlier works. More recently, critics such as Robert Hampson and Susan Jones have proposed a different approach to the romances of Conrad's later period. A case in point is Hampson's analysis of Lena's character in Victory. Unlike the earlier critics, who accused Conrad of sentimentality in female characterizations, Hampson argues that it is Lena herself who views her own being and her role in Heyst's life through a prism of sentimental romance. Lena's subjective perception of reality amounts to writing a script for herself (Hampson 2004), which casts her in the role of a sacrificial heroine. By using free indirect style, Conrad allows us to see Lena presented through her own idiom, in a manner comparable to Joyce's treatment of Gerty McDowell in Ulysses. The paper draws on Hampson's contention, exploring Conrad's narrative strategies in Victory, while also referring to the theoretical frameworks such as Genette's Narrative Discourse and Bakhtin's Dialogic Imagination.
\end{abstract}

Key words: Joseph Conrad, characterization, critical reception, free indirect style, subjectivity, Modernism.

Submitted March $9^{\text {th }}$ 2017, accepted for publication May $18^{\text {th }}, 2017$

Corresponding author: Nataša Tučev

University of Niš, Faculty of Philosophy, Niš, Serbia

E-mail: natasamlk@gmail.com 


\section{1. 'ACHIEVEMENT AND DECLINE': THE CRITICAL RECEPTION OF CONRAD'S ROMANCES}

Joseph Conrad is best known for the works written in the final years of the nineteenth and first decade of the twentieth century. This period, also known as his major phase, was the time of his greatest creativity, during which he produced his most famous and widely acclaimed novels: The Nigger of the 'Narcissus'(1897), Heart of Darkness (1899), Lord Jim (1900), Nostromo (1904), The Secret Agent (1907) and Under Western Eyes (1911). It is based on these novels that Conrad acquired a reputation as a 'profoundly masculine' writer, who 'works primarily off the masculine tradition of adventure fiction' (Dekoven 1999: 180). All attention in these writings is focused on the intense moral drama of his male protagonists, leaving little or no space for the development of the female ones. The assessment of most critics and reviewers is that when female characters do appear here at all, it is only to fill a space in the background of Conrad's novelistic canvas (Jones 1999: 14).

Conrad's later period, lasting from 1913 to 1923 , is characterized by a distinct shift in subject matter. Namely, all of the novels written in this decade (with the exception of The Shadow Line) demonstrate his newly discovered interest in romance and intimate erotic relationships. With the exploration of such themes, female characters also become more prominent and are assigned more important roles in the narrative than the heroines of Conrad's earlier works. However, it is exactly this feature of the novels such as Chance (1913), Victory (1915), The Arrow of Gold (1919), The Rescue (1920) and The Rover (1923), that according to numerous critics represents their weakest aspect and compromises their artistic value. ${ }^{1}$

Viewed chronologically, one of the first proponents of this negative view on Conrad's later novels was Virginia Woolf. Woolf 's review of The Rescue (published in TLS in 1920) begins with a neutral observation that in this novel - as well as in the preceding ones, such as Chance and Victory - Conrad seems to be 'attacking a new problem... different from those magnificently solved before' (Woolf 2005: 251). Viewed in itself, as Woolf points out, Conrad's novel exploration of the romantic genre needn't be regarded as either improvement or a failure, but simply as a new direction in his artistic development. However, by the end of her analysis, she reaches a conclusion that the romantic theme in The Rescue actually represents its 'central deficiency'. Conrad's attempt to create a romantic setting in which the two protagonists of The Rescue meet falls short of the standard set by his previous achievements. The reason is, as Woolf maintains, that Conrad does not fully believe in the romance he is presenting - and this makes his stylistic device sound artificial: '...beauty seems to be sought with effort, as though to bolster up some deficiency in the central idea. It is as if Mr. Conrad's belief in romance has suddenly flagged and he had tried to revive it by artificial stimulants' (Ibid., 253).

A more systematic approach to the same question is attempted in three distinguished critical studies written in the 1950s by Douglas Hewitt, Thomas Moser and Albert Guerard. The three critics reach an identical conclusion regarding a decline in literary

\footnotetext{
${ }^{1}$ In his discussion of the same issue, Ian Watt (2003: 181) also mentions a popular theory according to which Conrad 'turned to an emphasis on women characters, and love theme generally, because he thought this would make his novels popular' - in other words, because he thought they would bring him financial gain. Watt, however, refutes this theory, pointing out that Conrad actually exploited popular themes throughout his career but regularly failed in satisfying the popular taste, because he treated those themes 'in a very characteristically ironic way which trod hard... on optimistic attitudes'.
} 
quality in Conrad's novels written after Under Western Eyes. The most influential of the three was Moser's Joseph Conrad: Achievement and Decline, published in 1957. In the first chapter, titled 'The Early Conrad's Anatomy of Moral Failure', Moser argues that Conrad's best novels are those focusing on an individual's moral failure in the modern world and the causes thereof. In the second chapter, titled 'The Uncongenial Subject', Moser looks critically on romance which, in his opinion, is simply not suited to Conrad's temperament and artistic sensibility. 'There is something about the theme of love that elicits only bad writing from Conrad, something that frustrates his most strenuous efforts to create' (Moser 1966: 69). By 'bad writing' Moser means thematic, structural and stylistic weaknesses in Conrad's later works; he also maintains that Conrad's failure to represent his romantic subject is inseparable from his constant tendency to sentimentalize female characters. Especially in Chance and Victory, according to Moser, female characterizations are marred by the author's melodramatic devices. Moser argues that the heroines of these novels are unconvincing, inauthentic and incomparably less complex than the striking male protagonists of Conrad's earlier works (Ibid., 126).

Moser's view on romance as an 'uncongenial subject' for Conrad largely contributed to establishing a paradigm which has continued to dominate Conrad studies for decades to come. More recently, however, attempts have been made by several critics to challenge this paradigm by offering a different reading of Conrad's later novels. Among others, Robert Hampson and Susan Jones have proposed arguments for re-evaluating these works and reexamining the accusations directed at their romantic elements. In her study Conrad and Women (1999), Susan Jones maintains that even though the bulk of Conrad's writings is not dedicated to the issues of femininity, this author has, on the whole, always been 'a sympathetic interpreter of women's contemporary situation' (Jones 1999: 2). The novels such as Chance, Victory or The Arrow of Gold, according to Jones, actually represent Conrad's contribution to an on-going debate about female identity (Ibid., 4). In Conrad's later fiction, this issue is tackled in conjunction with his increased interest in visuality and the way it relates to gender; as Jones argues, Conrad 'emphasizes the gap between what a woman "is" and how she is represented' (Ibid., 49). Based on these premises, Jones pays especially close attention to Flora, the protagonist of Chance, and the investigations of gender and identity which Conrad conducts in this novel.

Another important example of re-evaluating female characterizations in Conrad's later novels is Robert Hampson's discussion of Lena's portrayal in Victory. Unlike Moser, who accused Conrad of sentimentality, Hampson argues that it is Lena herself who views her own being (and her role in the life of the novel's male protagonist, Heyst) through a prism of sentimental romance. Lena's subjective perception of reality, according to Hampson, amounts to 'writing a script for herself' (Hampson 2004: 145). He argues that Conrad achieves this effect by using free indirect style, thus enabling us to see Lena presented through her own idiom. Using Hampson's contention as a starting point, this narrative strategy will now be examined more closely.

\section{LENA'S CHARACTER AND FREE INDIRECT STYLE}

Free indirect style is frequently employed by the Modernist authors, and may also be viewed - as Gerard Genette explains - as an inherent feature of the novelistic genre in general. In his seminal study Narrative Discourse, Genette distinguishes between three 
basic ways in which a character's speech may be represented in fiction. It may be narrated, transposed indirectly or dramatised. Genette further elaborates on these three forms by relating them to the classical terms diegesis and mimesis: diegesis means rendering a character's speech in the narrator's voice, mimesis means imitating a character's own mode of expression, whereas indirect speech contains both the mimetic and diegetic elements (Genette 1980: 173). Genette also points out that in the novelistic practice these three forms are often intertwined and not clearly distinguished; this leads to the emergence of a variant known as free indirect style (style indirect libre in French or die erlebte Rede, 'experienced speech' in German). Free indirect style is characterized by subtle, imperceptible shifts from an impersonal third-person narration to a direct, personal expression of the words and thoughts of a character. It leaves out quotation marks and introductory phrases which would have conventionally marked for the reader whose speech is being recorded. As Genette explains, in free indirect style 'the narrator takes on the speech of the character, or, if one prefers, the character speaks through the voice of the narrator, and the two instances are then merged' (Ibid., 174).

While Genette points out that such merging of voices is an inherent feature of fiction in general, one may notice that in the twentieth century literature it is employed with greater frequency and extent than it was in the period of Realism. This quantitative difference may be explained by the Modernists' pervasive interest in subjectivism, and their endeavour to represent an individual's inner world in their writings as faithfully as possible. The same artistic goals have also lead to the appearance of the innovative technique of the stream of consciousness, whereby the narrative is completely contained within the mind of a character and the voice of authorial omniscience completely abandoned. In comparison to the stream of consciousness, free indirect style may be viewed as a kind of a compromise between the objective and the subjective: it is employed when, for some reason, the author wishes to maintain the presence of a more comprehensive consciousness, transcending the mind of any individual character in the novel.

In his discussion of free indirect style in Conrad's fiction, Jeremy Hawthorn (2013: 71-72) points out that this writing strategy should not be regarded as a mere technical device, but that Conrad's decision to employ it always has certain moral and ideological implications. In choosing how to represent a speech or thoughts of a character, Hawthorn maintains, Conrad simultaneously chooses the attitude that the narrative will take towards this character. Free indirect style therefore contributes to the perspective we are given; it involves the authorial decision 'as to how the reader is encouraged to see and to judge' a character whose consciousness is presented in this manner (Ibid., 75). Hawthorn also argues that free indirect style has been pervasive and present in Conrad's work from the onset, providing as an example the very first paragraph of his first novel, Almayer's Folly: 'The presence of FID $^{2}$ so early in Conrad's work suggests that it formed a natural part of his armoury of narrative techniques... we might even say that many characteristic Conradian features would have been impossible without it' (Ibid.). An especially important observation that Hawthorn makes is that a failure to recognize the use of this technique in Conrad's fiction may lead to serious misreadings - in other words, to 'an attribution of statements and sentiments to Conrad's authorial narrator instead of to the character' (Ibid.). It is exactly this kind of misreading which, in Hampson's opinion, led the earlier critics such as Moser to attribute Lena's romantic sentiment in Victory to Conrad himself.

\footnotetext{
${ }^{2}$ Instead of 'free indirect style' Hawthorn uses an equivalent term, 'free indirect discourse', or FID.
} 
In order to explain Conrad's approach to characterization in Victory, Hampson (2004: 157) suggests a comparison with the use of free indirect style in the works of James Joyce. Namely, in Joyce's works a specific approach to this writing technique is developed, which some critics also refer to as 'mimicry'. This is especially relevant to the way Stephen Dedalus is introduced in A Portrait of the Artist as a Young Man (1915) and some of the characters are introduced in Ulysses (1922). In these cases, we encounter passages of the novel 'which appear as if written by the characters who feature in them; as if the characters were somehow helping to tell their own story, shaping its style around their distinctive linguistic habits and expressive idioms' (Stevenson 1992: 47). The overall impression is that for each of these characters, Joyce has invented a cluster of idiomatic expressions which they would use if they were writing a novel. This is, for instance, the case with Gerty McDowell, who appears to be the 'author' of the first half of the thirteenth chapter of Ulysses: this part of the novel is purposefully written in a decorative, clichéd, cheaply romantic style parodying popular sentimental fiction and contemporary women's magazines, because these are the kinds of writings which to a great deal permeate Gerty's consciousness (Ibid.). Upon seeing Leopold Bloom on the shore of Sandymount, Gerty spins a romantic fantasy, casting him in the role of a mysterious stranger, whose life is for some reason fraught with misfortune and doom. Simultaneously she casts herself in the role of a sacrificial heroine who will heal him with her love:

There were wounds that wanted healing with heartbalm... She just yearned to know all, to forgive all if she could make him fall in love with her, make him forget the memory of the past. Then mayhap he would embrace her gently, like a real man, crushing her soft body to him, and love her, his ownest girlie, for herself alone (Joyce 1998: 342).

Joycean mimicry may also be explained in conjunction with Bakhtin's theories on 'character zones'. Namely, in analysing Turgenev's narrative techniques, Bakhtin focuses on the passages which (similar to Joyce's) appear to have been written by one of the characters and not by the author. In such passages, as Bakhtin explains, 'the entire emotional structure belongs to [the character]... This is his inner speech, but transmitted in a way regulated by the author' (Bakhtin 1981: 319). Such hybridizations, as Bakhtin calls them, stem from the fact that the important characters in a novel always generate a zone of influence surrounding them and extending beyond the boundaries of the direct speech allotted to them in the text: "The area occupied by an important character's voice must in any event be broader than his direct and "actual" words. This zone surrounding the important characters in the novel is stylistically profoundly idiosyncratic: the most varied hybrid constructions hold sway in it' (Ibid., 320).

It may be argued that Conrad's portrayal of Lena in Victory is characterized by the selfsame hybridization and mimicry - so that, in the parts of the narrative dealing with her character, the 'emotional structure' belongs to Lena and not to Conrad himself. This method is comparable to the one Joyce employed in representing Gerty McDowell, even though Joyce aimed at a parodic effect while Conrad did not. By using Gerty's own idiom, Joyce shows her inclination to sentimentalize not just her experiences, but also her notion of the self; the same may be said of Conrad's characterization of Lena. Lena's Victorian upbringing plays an important part in her perception of her own being. Her childhood was marked by financial difficulties and existential uncertainty since her father was a poor musician, hardly making a living by playing in small theatre orchestras. For Lena, the happiest memories of that period were of the times when she attended Sunday school with her landlady's daughters. Lena's 
inferior class position and her religious education have imposed on her a sense of femininity from which she derives her understanding of the self, as well as of the role she plays in Heyst's life:

[The narrative] shows how, from her different class position, she misreads and overvalues what in Heyst are merely marks of courtesy and how her low self-valuation shapes both her interpretation of Heyst's lack of emotional display and her response to it. Most interesting of all, the narrative shows how, under the influence of her Sunday school lessons and Victorian constructions of femininity, she writes a script for herself in which erotic feelings are displaced into idealistic self-sacrifice. The intrusion of Jones and company onto the island to which Heyst and Lena have withdrawn gives her the opportunity to cast herself in a drama of redemption, but the terms and structure of feeling in this drama derive from sentimental romance (Hampson 2004: 144-145).

Conrad's use of free indirect style in presenting Lena's subjective perception is especially prominent in the final scenes of the novel. Throughout the narrative, Lena yearns for an opportunity to prove her love to Heyst by some concrete gesture - but also for a way to awaken the same feelings in Heyst, whose lifelong habit of detachment and reflection has resulted in an overall sense of alienation, loss of affect and paralysis of will. She gets a chance to accomplish her goal when the terrifying Mr. Jones and his two companions, Ricardo and Pedro, suddenly intrude on the island which Heyst and Lena had made their home. By deceiving Ricardo, Lena manages to steal his knife, which she wants to give Heyst as a means of defence against the intruders ${ }^{3}$. However, soon afterwards she gets incidentally shot in a conflict which breaks out between Ricardo and Jones. When Heyst realizes that Lena is dying, and is too weak to lift her head, he tries to help her: 'With a terrible and gentle movement, Heyst hastened to slip his arm under her neck' (Conrad 1979: 324). The narrative then shows how Lena misinterprets this gesture, taking it as a proof that she has succeeded in awakening love in Heyst and thus achieving her great victory: 'Exulting, she saw herself extended on the bed, in a black dress, and profoundly at peace, while, stooping over her with a kindly, playful smile, he was ready to lift her up in his arms and take her into the sanctuary of his innermost heart - for ever!' (Ibid.). Based on the previous description, however, the reader knows that what Heyst displayed at that moment was only courtesy and kindness, rather than love which makes Lena's 'victory' much more problematic. The scene is therefore sentimental for Lena, but not for Heyst, nor for the narrative as a whole.

The final dialogue between Lena and Heyst, in Hampson's interpretation, really points to essential misunderstanding between the two protagonists. Lena seems to deliver her final lines speaking in front of Heyst, rather than engaging with him in a moment of mutual recognition. She is unaware that he cannot respond in kind to her feelings:

'Who else could have done this for you?' she whispered gloriously.

'No one in the world,' he answered her in a murmur of unconcealed despair (Ibid.).

\footnotetext{
${ }^{3}$ Lena's intention to acquire a knife for Heyst is in fact largely symbolical. Since it is stated several times in the novel that Jones, Ricardo and Pedro possess an entire stock of weapons, supplying Heyst with a single knife would hardly enable him to prevail against the trio. What Lena is trying to accomplish, in essence, is not saving Heyst from physical death, but from a kind of 'death-in-life', a spiritual and emotional paralysis caused by his inability to love (Meyers 2001: 291). Heyst also says of himself, 'I have been a disarmed man all my life' (Conrad 1979: 322), indicating that the novel views the loss of affect as a psychological equivalent of impotence. The same parallel between impotence and inability to love is drawn in the characterization of T. S. Eliot's protagonist Edward in The Cocktail Party.
} 
In the romantic script according to which Lena has sacrificed herself, this should have been the moment of their triumphant union in love - but instead, as Hampson points out, it is marked by division and difference (Hampson 2000: 146-147).

\section{SACRIFICE AND SUBJECTIVITY}

While Hampson defends Conrad successfully against the accusations of sentimentality, the problem with his interpretation is that it might make Lena's act of sacrifice appear delusional and insignificant. Based on Hampson's reading, one might conclude that the 'sentimental romance' through which Lena perceives her relationship with Heyst is completely divorced from reality. For this reason, it is important to stress that Lena's understanding of Heyst's alienated state, and of the way in which it could be transcended, is not at all off the mark. There are several motifs in the novel which point to the fact that Conrad did not intend to relativize Lena's nobility nor diminish the importance of her selfless sacrifice.

The significance of Lena's role in Heyst's life is symbolically suggested by her other name, Alma. We are told that Lena has two names, Magdalene and Alma, which point to different aspects of her personality and the different ways in which Heyst may perceive her. Mary Magdalene is presented in the gospels according to Mark and Luke as a repentant prostitute who becomes a follower of Christ: her figure alludes to Lena's own low-class origin and sordid life experience. Lena tells Heyst she hasn't come across many pleasant people in life, while he notices that her hands are 'not very white' (Conrad 1979: 71). It is also evident that Lena has internalized the stereotypes of the patriarchal culture as she says of herself that she is 'not what they call a good girl' (Ibid., 168). On the other hand, the name Alma points to some other potentials of Lena's personality. The word alma stems from the Latin alere, which means to feed. It appears in the syntagm Alma Mater, whose original meaning was 'bounteous, nourishing mother'; it was a title of the ancient Roman goddesses such as Ceres and Cybele (Cresswell 2010: 12). When Lena first meets Heyst, she is one of the performers in Zangiacomo's female orchestra, and is constantly threatened and harassed by Zangiacomo, as well as Schomberg, the keeper of the hotel in which they perform. This begins to make her uncertain about her sense of identity, which is why she invites Heyst to give her a new name. Heyst opts for the name Lena (short for Magdalene) as he believes it fits her life story and her desire for a new start; at the same time, his choice suggests that he sees himself in the superior role of Lena's 'saviour'. The events that follow, however, demonstrate that the name Alma would have been more appropriate for the girl and more in line with the qualities she would eventually display (Lybyer 1963: 29). By ignoring her other name, Heyst shows he is not aware that Lena might be his saviour, a nourishing feminine or a spiritual guide.

During their stay on the island, Lena realizes Heyst has rescued her out of pity and not out of love. In spite of this, the narrative represents her love towards Heyst as unconditional. In this respect, Lena resembles Shakespeare's heroines - perhaps more so than any other female character created by Conrad. It is possible that Conrad, who was reading A. C. Bradley's wellknown study Shakespearean Tragedy (1905) at the time when he was composing Victory ${ }^{4}$, was influenced by Bradley's analyses of Shakespeare's heroines. Lena is similar to Juliet or

\footnotetext{
${ }^{4}$ Hampson (2004: 145) mentions this biographical detail in his discussion of Victory. He does not, however, consider Shakespeare's possible influence on the development of Lena's character, but only comments on Conrad's renewed interest in dramatic dialogue.
} 
Desdemona in the sense that love incites her to transform and grow, providing her with courage and moral strength. ${ }^{5}$ As opposed to an earlier scene in the novel, where Lena was weak and helpless against Schomberg's advances, in a later scene she overpowers Ricardo without any difficulties. Lena's love has not only increased her own sense of self-worth, but also made her aware that this time she needs to fight both for herself and Heyst: 'She resisted without a moment of faltering... because she was a human being who counted; because she was no longer defending herself for herself alone' (Conrad 1979: 239).

In spite of all the misunderstandings between Lena and Heyst, and the seemingly insurmountable differences in their social background, education and habits of life, Lena intuits the essence of Heyst's problem and, in her own terms, proposes a correct diagnosis and cure - by telling him, 'You should try to love me!' (Ibid., 188). Her act of sacrifice, sadly, only enables Heyst to reach a negative insight regarding his wrong existential choices and the lost possibility of a fulfilled life; incapable of a new beginning, he commits suicide. In this respect, Heyst is just one of the numerous Conradian heroes for whom self-knowledge comes too late - and may be summed up, as Marlow grimly remarks in Heart of Darkness, as 'a crop of inextinguishable regrets' (Conrad 1999: 98).

\section{CONCLUSION}

While there are authors who accuse Conrad of being sentimental and melodramatic in portraying Lena in Victory, it may be argued that sentimentality really stems from Conrad's intention to represent this character through her own idiom. By referring to the theoretical works written by Genette and Bakhtin, it is possible to demonstrate that what Conrad achieved was in fact a hybridization of discourses - the speech of the author merged with the speech of a character - which was a narrative strategy misunderstood by some of the earlier critics.

Conrad's approach to characterization in this case needs to be understood within the wider context of the Modernists' poetics and the pervasive interest of these authors in subjectivity. Modernist fiction often presents us with individuals whose inner life is permeated by fantasies. However, as Martha Nussbaum points out in her analysis of Ulysses, 'without the energy of fantasy we might not have the imagination of another's good or ill'. It is true, as Nussbaum concedes, that Gerty McDowell's fantasies and day-dreams distort reality - but they also enable her to get 'a sense of Bloom's suffering' and experience empathy with the other (Nussbaum 2001: 704). The same may be argued of Lena's subjective perception in Victory. By writing 'a script for herself', Lena actually finds a way of connecting with Heyst imaginatively and understanding his predicament.

\footnotetext{
${ }^{5}$ In his seminal study Shakespeare and the Goddess of Complete Being, Ted Hughes also discusses the total, unconditional surrender to love which is the defining feature of some of Shakespeare's heroines. They 'ignore any apparent change in their beloved, ready to immolate themselves on the subjective truth and loyalty of their love' (Hughes 1993: 60). Hughes believes that this kind of most intimate surrender and self-exposure in love, which also appears as a motif in Shakespeare's sonnets, practically disappeared from the English literature after the bard's death.
} 


\section{REFERENCES}

Bakhtin, M., (1981), The Dialogic Imagination, trans. C. Emerson and M. Holquist, University of Texas Press, Austin.

Conrad, J., (1999), Heart of Darkness and Other Stories, Wordsworth Editions, Ware.

Conrad, J., (1979), Victory, Penguin, Harmondsworth.

Cresswell, J., (2010), Oxford Dictionary of Word Origins, OUP, Oxford.

Dekoven, M., (2005), 'Modernism and Gender'. In: Levenson, M. (ed.) The Cambridge Companion to Modernism, CUP, Cambridge, pp. 174-193.

Genette, G., (1980), Narrative Discourse: An Essay in Method, transl. J. E. Lewin, Cornell University Press, Ithaca. Hampson, R., (2000), Cross-Cultural Encounters in Joseph Conrad's Malay Fiction, Palgrave, New York.

Hampson, R., (2004), 'The Late Novels'. In: The Cambridge Companion to Joseph Conrad, CUP, Cambridge, pp. $140-159$

Hawthorn, J., (2013), 'Seeing and Believing: Represented Thought and Speech in Conrad's Fiction'. In: Roberts,

A. M. (ed.) Joseph Conrad, Routledge, London and New York, pp. $71-90$.

Hughes, T., (1993), Shakespeare and the Goddess of Complete Being, Faber and Faber, London.

Jones, S., (1999), Conrad and Women, OUP, Oxford.

Joyce, J., (1998), Ulysses, OUP, Oxford.

Lybyer, J. M., (1963), Conrad's Victory: Notes, Cliffs, Lincoln.

Meyers, J. (2001), Joseph Conrad: A Biography, Cooper Square Press, New York.

Moser, T., (1996), Joseph Conrad: Achievement and Decline, Archon Books, Hamden.

Nussbaum, M., (2001), Upheavals of Thought, CUP, Cambridge.

Stevenson, R., (1992), Modernist Fiction: An Introduction, Harvester Wheatsheaf, Hemel Hempstead.

Watt, I., (2003), Essays on Conrad, CUP, Cambridge.

Woolf, V., (2005), 'A Disillusioned Romantic'. In: Sherry, N. (ed.) Joseph Conrad: The Critical Heritage, Routledge, London, pp. 251-253.

\section{LIČNI SCENARIO: KARAKTERIZACIJA I SLOBODNI INDIREKTNI STIL U POBEDI DŽOZEFA KONRADA}

Pedesetih godina dvadesetog veka, tri zapažene studije o Džozefu Konradu čiji su autori Daglas Hjuit, Tomas Mozer $i$ Albert Džerard, uslovile su nastanak kritičke paradigme koja je potom još decenijama bila dominantna u proučavanju Konradovog opusa - a naročito u negativnoj oceni umetničke vrednosti njegovih poznih romana. Glavni razlog za pad umetničkog kvaliteta u Konradovoj poznoj fazi, po njihovom mišljenju, leži u promeni izbora tematske građe od romana Prilika na dalje - to jest, u Konradovom novom interesovanju za romansu. Konradovo neuverljivo predstavljanje ljubavne tematike u ovim delima, po Mozerovom mišljenju, tesno je povezano i sa neuverljivom karakterizacijom ženskih likova i autorovom tendencijom da ih sentimentalizuje.

Poslednjih decenija, međutim, u kritici su učestali pokušaji da se odstupi od ove paradigme i ponudi drugačije čitanje Konradovih poznih romana. Kritičari kao što su Robert Hampson i Suzan Džons iznose argumente za reevaluaciju ovih dela i preispituju optužbe na račun njihovih romantičnih elemenata. Tako Hampson odbacuje teoriju po kojoj Konrad sentimentalizuje Lenin lik u romanu Pobeda - tvrdeći, umesto toga, da Lena sama za sebe piše scenario u žanru sentimentalne romanse. Koristeći slobodni indirektni stil, Konrad nam predstavlja Lenin lik putem njenog sopstvenog idioma, što je postupak sličan Džojsovoj reprezentaciji lika Gerti Mekdauel u Uliksu. Ovaj rad dalje razvija Hampsonovu tezu $i$ istražuje Konradove narativne strategije u Pobedi, pozivajući se pri tom na teorije Mihaila Bahtina $i$ Žerara Ženeta.

Ključne reči: Džozef Konrad, karakterizacija, kritička recepcija, slobodni indirektni stil, subjektivnost, modernizam. 